\title{
The distribution of genus Hippobosca in Transcaucasia
}

Emilia Petrovna Nartshuk \& Jozef Oboňa

The distribution of genus Hippobosca in Transcaucasia. - Acta Mus. Siles. Sci. Natur., 68: 257-261, 2019.

\begin{abstract}
The unpublished zoogeographical views of louse flies from genus Hippobosca deposited in Collection of the Zoological institute of Russian Academy of Sciences in St. Petersburg, Russia from Transcaucasia are summarized. A total 248 deposited samples and one recent sample belonging to species Hippobosca equina Linnaeus, 1758 and Hippobosca longipennis Fabricius, 1805 from Armenia, Azerbaijan, Georgia, Southern Caucasus and north-western Iran are presented.
\end{abstract}

Key words: Hipoboscidae, Hippobosca equina, Hippobosca longipennis, Armenia, Azerbaijan, Georgia, Russia, Southern Caucasus, Iran

\section{Introduction}

Hippobosca is a genus of family Hippoboscidae with seven described species. All species occur in Africa and the Middle East with the ranges of three species extending into the Oriental region and southeast Asia (Hutson 1984). The global distribution can be found in Maa (1962, 1969), distribution for the Palaearctic region in Theodor \& Oldroyd (1964) or Doszhanov (2003). Very common and most frequently studied Palaearctic and West Oriental species of this genus is Hippobosca equina Linnaeus, 1758. It is a ectoparasite of livestock, preferably horses, donkeys, cows and dogs, but occasionally parasitizing also humans (Krištofík 1998, Halos et al. 2004, Oboňa et al. 2019a). In Western Europe it recent occurrence is strongly affected by a decline of traditional horse and sheep farming (e.g. Bezák \& Petrovič 2006). All species of this genus are bloodsucking ectoparasites, which are also known as possible vectors of various diseases (Baker 1967, Oyieke \& Reid 2003, Halos et al. 2004, Zabashta et al. 2017).

Transcaucasia is known with a persisting of traditional domestic's animals farming (Fig. 1). This situation creates suitable conditions for the survival of many species, with are almost extinct in other countries (e.g. Western Europe). The good example can be also species H. equina. On the other hand, it must be emphasized, that precisely those areas are insufficiently investigated particularly in terms of biodiversity of selected Diptera families (e.g. Oboňa et al. 2016, 2017) and published data about the family Hippoboscidae are also poorly.

From territory of Armenia are available records of Melophagus ovinus (Linnaeus, 1758) (Movsessyan et al. 2013), Ornithophila gestroi (Rondani 1878) (Nartshuk \& Matyukhin 2019) and Icosta ardeae (Macquart, 1835) (Matyukhin et al. 2016). Maa (1962) mentioned occurrence of species Hippobosca longipennis Fabricius, 1805 from Georgia (no other data) and Maa (1969) mentioned occurrence of species H. equina from Transcaucasia. From territory of whole Iran are recently published species Ornithophila metallica (Schiner, 1864), and Pseudolynchia canariensis (Macquart in Webb \& Berthelot, 1839) (Pirali-Kheirabadi et al. 2016, Araghi et al. 2017). Older papers published species Hippobosca variegata Megerle, 1803, Icosta ardeae (Macquart, 1835) - as Lynchia albipennis Say, 1823 (Theodor \& Oldroyd 1964) and Ornithoica bistativa Maa, 1966, H. equina, H. longipennis, H. camelina Leach, 1817, Lipoptena capreoli Rondani, 1878, and Lipoptena arianae Maa, 1969 in Maa (1969).

Therefore, the main objective of this paper is to publish unpublished data of genus Hippobosca from Transcaucasia. 


\section{Material and methods}

The material of 248 studied specimens, as a part of the louse flies collection, is deposited in the Zoological institute of Russian Academy of Sciences, St. Petersburg, Russia (ZISP). Dry and pined flies were re-examined by the first author (Note: some old labels before 1917 are now difficult to interpreted). The one recently captured specimen (hand collecting from cow by Libor Dvořák) is preserved in ethanol, identified by the second author, and it is deposited in ethanol collection in the Laboratory and Museum of Evolutionary Ecology, Department of Ecology, University of Prešov (LMEE).

The following abbreviations are used: sp. - sample; sps. - samples; Mts. - mountains; coll. - collector.

\section{Results}

A total 194 specimens of $H$. equina from Transcaucasia are deposited in ZISP and one female is deposited in LMEE.

\section{Hippobosca equina Linnaeus, 1758}

\section{Material}

Armenia: Aragatsotn, Byurakan village, canyon of river Amberd, 9.vii.1957, coll. V. Rikhter, 1 sp.; Syunik, Meghri village, near the river Aras, 17.iv.1960, coll. V. Rikhter, 1 sp.

Azerbaijan: "Geoktepe(Ağdaş), Elisavetinskaya gubernia (Gəncə), Areshkinsky uesg.”, 26.vi.1901, coll. P. Shmit, 1 sp.; Elisavetinskaya gubernia”, 14. - 19.v.1909, coll. Bebedurashipe, 1 sp.; "Dokeforkan”, 21.v.1923, coll. Lukyanovich, 1 sp.; "Alerseevka, 12 km SW Lankaran, 5.vii.1932, coll. Znoiko, 1 sp.; Lerik, Lyulyakeran, Zuvand, 2.viii.1932, coll. Znoiko, 1 sp.; Lyulyakeran, Zuvant, 2.viii.1932, Znoiko, 1 sp.; Nakhichevan, Tyllyakh on river Gilanchai, 4.viii.1933, coll. Znoiko, 2 sps.; Nakhichevan, Chagla-dora near Kaputzhukh (Ordubad rayon, near Parağa), 1933, coll. Znoiko, 1 sp.; Ordubad, valley of river Aras, 15.vii.1933, coll. Znoiko, 3 sps.; Ordubad, Duchar near Ordubad, 23.vii.1933, Znoiko, 1 sp.; Nakhichevan region, 31.v.1934, Kirshenblat, 4 sps.; Ordubad, viii.1902, coll. Satunin, 1 sp.; 5.vi.1934, coll. Kirshenblat, 6 sps.; Astara, river Talysh, on horse, 8-9.viii.1938, Veltishchev, 7 sps.; Lerik, Astarin on river Talysh, 8-9.viii.1938, coll. Veltishchev, 7 sps.; Ordubad, 7.v.1939, coll. Gauser, 10 sps., 2.viii.1939, coll. Bogachev, 1 sp.; Ordubad, 9.viii.1939, coll. Bogachev, 1 sp.; Ordubad, 7.v.1939, coll. Gauser, 10 sps.; Ordubad on river Ayaks, 22.-24.vi. 1955, coll. Zagulyaev, 2 sps.; Ordubad; Bilav, 25.vi.1967, coll. V. Rikhter, 2 sps.; Kosmolyan Lerik, Talysh, 22.v.1969, coll. Tanasijtshuk, 1 sp.; Lerik, Gosmalijion, Talysh, 22.v.1969, coll. Tanasijtshuk, 1 sp.; Ordubad, Nusnus, near Ordubad, 3.vi.1974, coll. Volkovich, 1 sp.; Kakhi, 18.v.1978, coll. V. Rikhter, 1 sp.; Zaqatala, tributary of the Talacaj (Talachay) above Car, forest at riverbanks, on cow, 9.v.2019, 41 ${ }^{\circ} 40^{\prime} 40.7^{\prime \prime} \mathrm{N}$ 46²4'57.9"E, coll. Dvoř́ák, 1 female (fig. 2).

Georgia: Tbilisi, 1862, coll. Satunin, 1 sp.; Kutais (= Kutaisi), 1875, Il'in coll., 1 sp.; Kakheti, vicinity of Lagodekhi, 10.x.1896 and 6.vii.1916, coll. Mlokosevich, 28 sps.; S slope of the Main Ridge near Lagodekhi, 26.vii.1913, coll. Mlokosevich, 1 sp.; Murguz, mountain ridge in Malyi Caucasus, N-W from Lake Sevan, 13.viii.1915, coll. Satunin, $1 \mathrm{sp}$.

Adjara: Adjara, 29.vii.1909, coll. Satunin, 1 sp.; Kobuleti, 7-9.vii.1910, coll. Satunin, 2 sps.; Chakvistavi, 22-23.vii.1971, Zagulyaev, 3 sps.; Kintrishi Nature Reserve, 25.vi.1974, coll. Zagulyaev, 1 sp.

Abkhazia: Abkhazia, Gagra, 2.vii.1900, coll. Bykov, 15 sps.; Marukh Mts. near Chkhalta, $1400 \mathrm{~m}$ a.s.l., 7.viii.1905, coll. Kalishevski, 1 sp.; Suchumi, 2.viii.1928, coll. Gudim, 23 sps.; Bzybsky Mts., NE slope of Tshipshira Mts., $2200 \mathrm{~m}$ a.s.1., 10-30.viii.2010, coll. Gobunova and Spodobin, 1 sp.

Daghestan (Russia): Kayakent, 31.vii.1910, coll. Satunin, 1 sp.; Alesandronevskaya near Kizljar, 17.vi.1913, coll. Mlokosevich, 1 sp.; the same, 9.vi. and 9.vii.1927, coll. Olsufiev, 2 sps.; the same, 2.vi.1927, coll. Popova, 1 sp.; Derbent, iv.1917, coll. Olsufiev, 1 sp.; Kurush, 24.viii.1924, coll. Pyabov, 2 sps.; Gunib, 1800 m a.s.l., 1.x.1976, coll. Zaitzev, $1 \mathrm{sp.}$

Krasnodar Krai (Russia): vicinity of Sochi, 1900, coll. Stark, 3 sps.; the same 16.vi.1927, coll. Gudim, 1 sp.; Gelendzhik, 25.viii.1908. coll. Vorobiev, 1 sp.; between Nizhnegorskoi and Guamski karaul, 10.viii.1910, coll. Birulya, 9 sps.; Nebut vicinity of Tuapse, 13.viii.1912, coll. Gitterman, 2 sps.; Ashe near Sochi, 11.vii.1913, coll. Nasonov, 1 sp.; Tuapse, river Shapsi, on horse, (no date), coll.Gorchakovski, 10 sps.; Golovinka, river Bsyb, on men, 16.vii.1950, coll. Gussakovski, 1 sp.

Iran (north-western ): Vic Agar', north-western Persia, 12.vi.1914, von Wick, 5 sps.; Gasan-beglyu-Saroga-darya, Karag, 8.vi.1914, von Wick, 3 sps. 
A total 54 specimens of $H$. longipennis from Transcaucasia are deposited in ZISP.

\section{Hippobosca longipennis Fabricius, 1805}

\section{Material}

Armenia: Yerevan, 7.vi.1921, coll. Popov, 4 sps.

Azerbaijan: Baku, 1863, coll. Gebel, 6 sps.; Boradigah, NW of Lankaran, 4.vii.1910, coll. Satunin, 1 sp.; Aghstafa, 7.vii. and 5.ix.1915, coll. Satunin, 2 sps.; Near Karamaryan, Geokch, uezg. (Geokchaisky rayon with center Geokchay), 19.vi-1.vii.1923, coll. Gorchakovsky, 8 sps.; Dzhaffarkhan, 2.viii.1927, coll. Bocharnikov, 2 sps.; Ordubad, valley of river Aras, 6.vii.1933, coll. Znoilo, 1 sp.; Ordubad, 5.vi.1934, coll. Kirshenblat, 4 sps.; Nakhichevan, 4.viii.1961, on man, without collector, 1 sp.; Shaki, Nukha env. of Sheki, 1600 m a.s.l., 27.vii. and 12.viii.1966, on horse and cow, coll. Amirkhanov, 5 sps.

Georgia: Tbilisi, 1802, coll. Satunin, 1 sp.

Abkhazia: Abkhazia, Kobuleti, 8-30.vi.1909, 24.vii. and 5.viii.1910, coll. Satunin, 8 sps.

Daghestan (Russia): Derbent, 28.vii.1910, coll. Satunin, 1 sp.; Alesandronevskaya near Kizljar, 22.viii.1922, 22-24.v and 2-3.vi.1927, coll. Olsufiev, 7 sps.

Krasnodar Krai (Russia): Khutor Sosnovka, 19.v. without year, coll. Filipchenko, 2 sps.; Sochi, 1900, coll. Stark, $1 \mathrm{sp}$.

\section{Conclusion}

As mentioned above, $H$. equina is very common and most frequently species of genus Hippobosca (e.g. Krištofík 1998), which would also be confirmed by samples deposited in ZISP from Transcaucasia. The lack of current findings, may be caused, by among other factors, that standard collection methods e.g. sweep netting, light trapping etc. (see e.g. Oboňa et al. 2016, $2017,2019 b$ ) are not suitable for capture these ectoparasites. The best collection method seems to be hand collecting from their hosts. The second species $H$. longipennis is less numerous in this area according the samples deposited in ZISP. We assume, that $H$. longipennis has a boundary of northern distribution here.

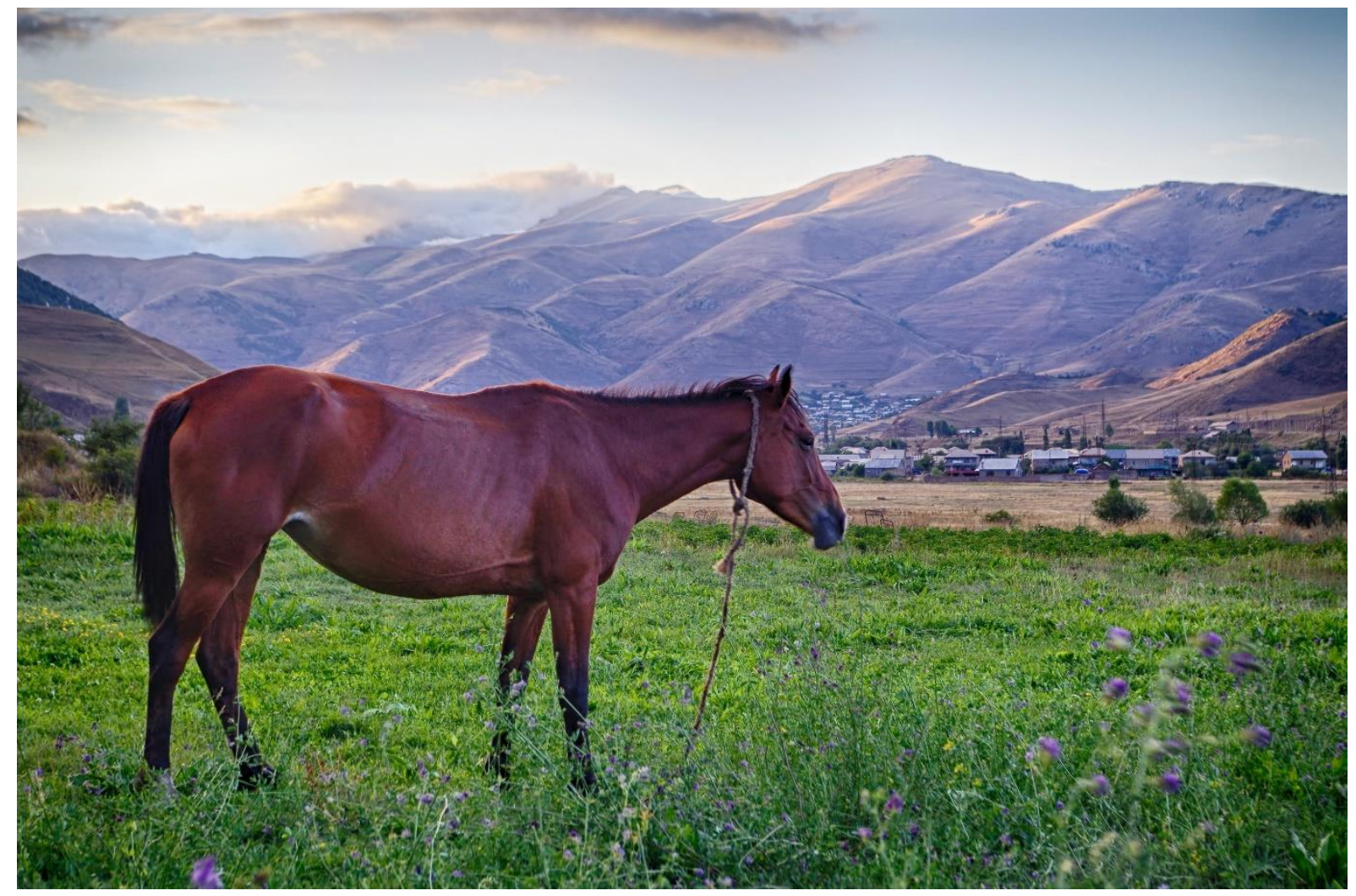

Fig 1: The traditional domestic's animals farming in Transcaucasia (photo P. Manko). 


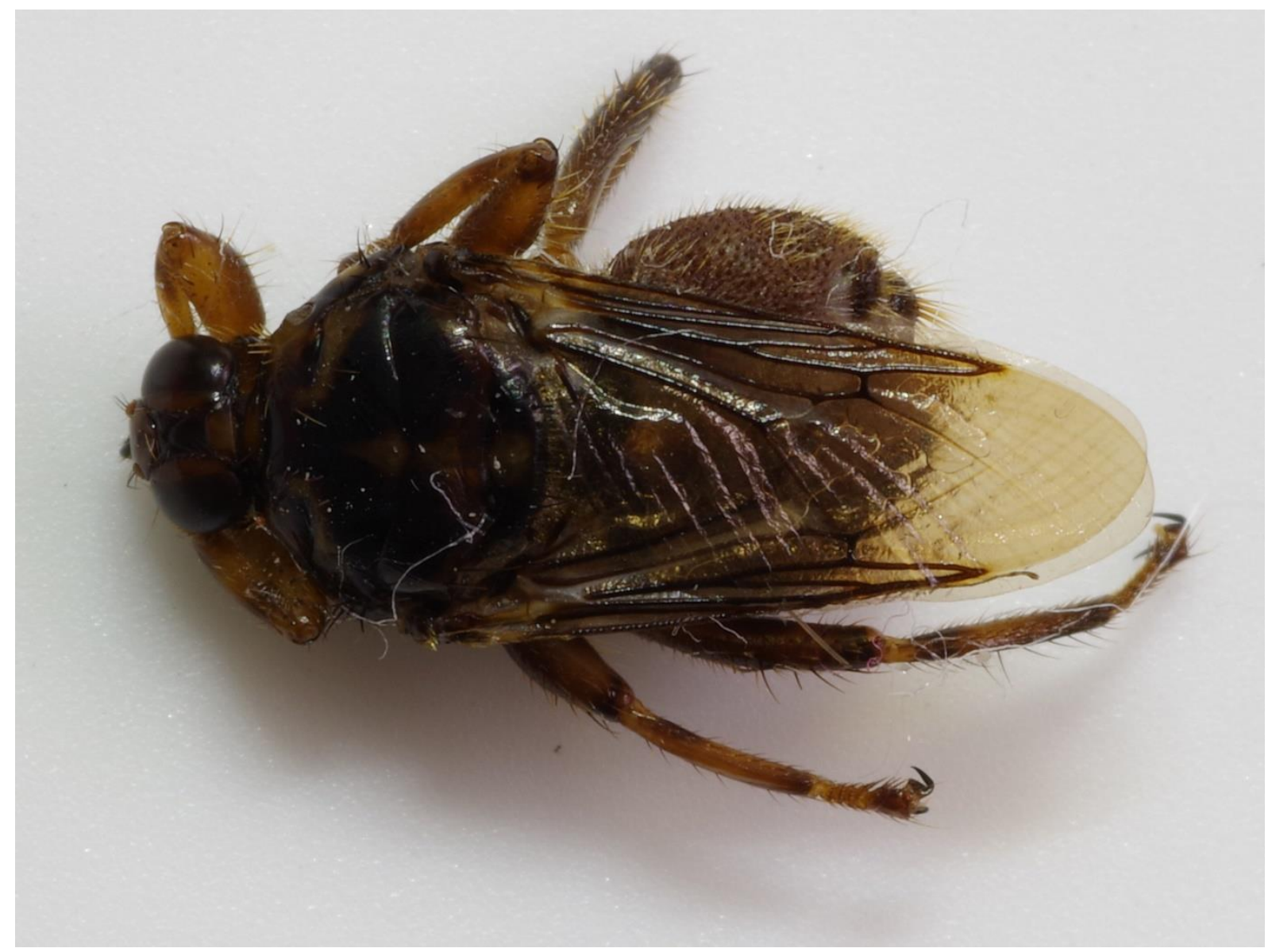

Fig 2: The specimen of Hippobosca equina Linnaeus, 1758 from Azerbaijan (Zaqatala, above Car village, from cow (photo P. Manko).

Acknowledgements: We would especially like to thank to the editor and reviewers for their valuable and constructive comments on the first version of the manuscript, P. Manko (Univerzity of Prešov, Slovakia) for permission to use his macrophotograph, and D. A. Gapon and M.G. Volkovich (Zoological institute of Russian Academy of Sciences) for help with clarify of some old geographical names. E. P. Nartshuk's study was supported by the grant AAAA-A19-119020690082-8. J. Oboňa's study was supported by the Slovak Research and Development Agency under contract No. APVV-16-0411 and by the International Visegrad Fund (project No. 21810533).

\section{References}

Araghi M.P., Gilasian E. \& Samaie A. (2017): New Records of Bloodsucking Flies Associated with Wild Birds of Haftad-Gholleh Protected Area, Iran (Diptera: Hippoboscidae, Calliphoridae). - Journal of Biodiversity and Endangered Species 5: 184.

Baker J.R. (1967): A review of the role played by the Hippoboscidae (Diptera) as vectors of endoparasites. Journal of Parasitology 53(2): 412-418.

Bezák P. \& Petrovič F. (2006): Agriculture, landscape, biodiversity: scenarios and stakeholder perceptions in the Poloniny National Park (NE Slovakia). - Ekológia (Bratislava) 25(1): 82-93.

Doszhanov T.N. (2003): Louse-flies (Diptera, Hippoboscidae) of the Palearctic region. Almaty, 277 pp. [In Russian]

Halos L., Jamal T., Maillard R., Girard B., Guillot J., Chomel B., Vayssier-Taussat M. \& Boulouis H.J. (2004): Role of Hippoboscidae flies as potential vectors of Bartonella sps. infecting wild and domestic ruminants. - Applied and Environmental Microbiology 70(10): 6302-6305.

Hutson A.M. (1984): Diptera: Keds, flat-flies \& bat-flies (Hippoboscidae \& Nycteribiidae). Handbooks for the Identification of British Insects. Royal Entomological Society of London, $84 \mathrm{pp}$.

Krištofík J. (1998): Louseflies (Diptera, Hippoboscidae) in the collections of František Balát. - Acta Musei Moraviae, Scientiae biologicae 83: 211-216. 
Maa T. C. (1962): Notes on the Hippoboscidae (Diptera), 1. - Pacific Insects 4: 583-614.

- (1969): A revised checklist and concise host index of Hippoboscidae (Diptera). - Pacific Insects Monograph 20: 261-299.

Matyukhin A.V., Zabashta A.V., Babichev Yu.V. \& Boyko Ye.A. (2016): Icosta ardea (Ornithomyinae, Hippoboscidae) v Palearktyke. - The Fauna and Ecology of Parasites 49: 66-68.

Movsessyan S.O., Boyakhchyan G.A., Chubaryan F.A., Petrosyan R.A., Arutyunova L.D. \& Nikogos yan M.A. (2013): Composition of parasite fauna of sheep contained within limited territories in the foothill zones of Armenia. - Rossijskij Parazitologicheskij Zhurnal 1: 16-23.

Nartshuk E.P. \& Matyukhin A.V. (2019): The louse flies Ornithophila metallica (Schiner 1864) and O. gestroi (Rondani 1878) (Diptera, Hippoboscidae): distribution and association with birds in the Palaearctic. Zoologicheskij Zhurnal 98(6): 630-633.

Oboňa J., Dvořák L., Haenni J.-P., Hrivniak L., Japoshvili B., Ježek J., Kerimova I., Máca J., Murányi D., Rendoš M., Słowińska I., Snegovaya N., Starý J. \& Manko P. (2019b): New and interesting records of Diptera from Azerbaijan and Georgia. - Zoosystematica rossica (in press).

Oboňa J., Dvořák L., Haenni J.P., Manko P., Hrivniak L. \& Papyan L. (2017): New records of Diptera families Anisopodidae, Bibionidae, Dixidae, Ptychopteridae, and Scatopsidae from Armenia. - Spixiana 40(1): 61-67.

Oboňa J., Starý J., Manko P., Hrivniak L. \& Papyan L. (2016): Records of Limoniidae and Pediciidae (Diptera) from Armenia, with the first Armenian checklist of these families. - ZooKeys 585: 125.

Oboňa J., Sychra O., Greš S., Heřman P., Manko P., Roháček J., Šestáková A., Šlapák J. \& Hromada M. (2019a): A revised annotated checklist of louse flies (Diptera, Hippoboscidae) from Slovakia. - ZooKeys 862: $129-152$

Oyieke F.A. \& Reid G. (2003): The mechanical transmission of Trypanosoma evansi by Haematobia minuta (Diptera: Muscidae) and Hippobosca camelina (Diptera: Hippoboscidae) from an infected camel to a mouse and the survival of trypanosomes in fly mouthparts and gut (a preliminary record). - Folia Veterinaria 47(1): $38-41$.

Pirali-Kheirabadi K., Dehghani-Samani A., Ahmadi-Baberi N. \& Najafzadeh V. (2016): A First Report of Infestation by Pseudolynchia canariensis in a Herd of Pigeons in Shahrekord (Southwest of Iran). Journal of arthropod-borne diseases 10(3): 424.

Theodor O. \& Oldroyd H. (1964): Hippoboscidae. In: Lindner, E. (ed.) Die Fliegen der Palaearktischen Region - 12, Schweizerbart, Stuttgart, Germany, pp. 1-70.

Zabashta M.V., Pichurina L.N., Matyukhin A.V., Savchenko A.P., Romanova L.V. \& Zabashta A.V. (2017): The epizootological importance of the numerous species of bloodsucking flies (Diptera: Hippoboscidae) of the Western Ciscaucasia. pp. 191-193. In: XV Congress of the Russian Entomological Society. Russia, Novosibirsk, July 31 - August 7, 2017. Materials of the Congress, 576 pp. [In Russian]

Authors' address: Emilia Petrovna Nartshuk, Zoological institute of Russian Academy of Sciences, Universitetskaya nab. 1, RU-199034 St. Petersburg, Russia

E-mail: chlorops@zin.ru

Jozef Oboňa, University of Prešov, Faculty of Humanities and Natural Sciences, Department of Ecology, 17. novembra 1, SK-081 16 Prešov, Slovakia

*Corresponding author. E-mail: obonaj@centrum.sk 